\title{
The Effect of TGT Model on Student Cognitive Learning Outcomes: The Concept of Relay Running
}

\author{
Albertus Fenanlampir' \\ DOI: $10.35445 /$ alishlah.v13i3.1409
}

\begin{abstract}
Article Info
Abstract

Keywords:

Physical education;

TGT Cooperative;

Cognitive learning

outcomes;

Relay running

TGT cooperative type learning, as a game-based learning methodology, provides opportunities for students to develop skills in group interactions in small groups and work together with others. The world of learning today needs phenomena like this. This study aimed to determine the effect of the TGT cooperative type learning model on students' cognitive learning outcomes on the topic of relay running. This quantitative study was a quasi-experimental pretest-posttest design. The samples involved were 70 students from two different experimental and control classes. The data collection instrument in this study was 10 essay test questions validated and tested. The results showed an effect of the TGT cooperative type learning model on students' cognitive learning outcomes. The achievement test score for the TGT group was 81.67, while the control group was 75.75. It implies that the TGT group performed superior in cognitive learning outcomes when compared to the control group. Thus, it is concluded that the TGT cooperative type learning model can be recommended in improving students' cognitive learning outcomes on the concept of relay running.
\end{abstract}

Kata kunci:

Pendidikan jasmani;

Kooperatif TGT;

Hasil belajar kognitif;

Lari estafet

\begin{abstract}
Pembelajaran kooperatif tipe TGT, sebagai metodologi pembelajaran berbasis game yang memberikan kesempatan kepada siswa untuk berkembang secara keterampilan dalam interaksi kelompok pada kelompok kecil dan bekerja sama dengan orang lain. Fenomena seperti ini yang dibutuhkan oleh dunia pembelajaran saat ini. Tujuan dari penelitian ini adalah mengetahui pengaruh model pembelajaran kooperatif tipe TGT terhadap hasil belajar kognitif siswa pada topik lari estafet. Sebuah penelitian kualitatif dengan desain pretestposttest dengan quasi-eksperimental. Jumlah sampel yang terlibat sebanyak 70 siswa dari dua kelas berbeda yaitu eksperimen dan kontrol. Instrumen pengumpulan data dalam penelitian ini berupa 10 soal tes uraian yang telah divalidasi dan diuji coba. Hasil penelitian menunjukkan bahwa ada pengaruh model pembelajaran kooperatif tipe TGT terhadap hasil belajar kognitif siswa. Skor tes prestasi untuk kelompok TGT adalah 81,67, sedangkan kelompok kontrol adalah 75,75. Ini menyiratkan bahwa kelompok TGT tampil lebih uggul dalam hasil belajar kognitif bila dibandingkan dengan kelompok kontrol. Dengan demikian disimpulkan bahwa model kooperatif tipe TGT dapat direkomendasikan dalam meningkatkan hasil belajar kognitif siswa pada konsep lari estafet.
\end{abstract}

\section{INTRODUCTION}

Physical education is a continuous activity initiated based on current educational developments (Luo et al., 2020). The main goal of physical education is to offer physical, but how to learn makes students stronger and healthier. In addition, it helps students gain knowledge,

${ }^{1}$ Universitas Pattimura, Ambon, Indonesia

Email: fenanlampir29@gmail.com

Vol.13 (3) December, 2021

Received: November 29, 2021; Received in revised form: December 7, 2021; Accepted: December 24, 2021; Available online: December 31, 2021. This is an open access article under a Creative Commons Attribution-NonCommercial-ShareAlike 4.o International License. 
experience, emotional interaction, and team collaboration that significantly impact being able to live in the future when they leave school (Groffik et al., 2020). In contemporary society, cooperation between groups becomes essential in line with the development of science and technology today. Communities need to develop the behaviour to cooperate with others, especially in education and develop skills (Casey \& Fernandez-Rio, 2019). The Program for International Student Assessment (PISA) explains that $87 \%$ of learning has been problem-solving, collaborative, critical, and creative (He et al., 2019). It shows that learning is more directed at cooperative learning (Leasa et al., 2016). As part of a new teaching trend in education that shifts traditional didactic learning that is independent (Healy et al., 2018). Today, cooperative learning and problem-solving skills are the focus of international attention (Liebech-Lien, 2021).

Physical education only teaches one-way skills without stimulating students to love sports and peer interaction. This pattern of activities will make students bored because the teacher does monotonous teaching, causing students to lose motivation to continue exercising (André et al., 2011); (Bjørke \& Mordal Moen, 2020). Suppose this activity is carried out in the same style and pattern. In that case, it will decrease students' competence and cognitive learning outcomes (Casey \& Quennerstedt, 2020). Teachers must demonstrate interpersonal skills in designing teaching to grow students' knowledge and habits related to sports while creating a learning environment that encourages students to be more active (Rivera-Pérez et al., 2020).

Since the 1970s, many educational scientists have developed a cooperative learning model of team-game tournaments (TGT). TGT was initially developed by David DeVries and Keith Edwards of Johns Hopkins University as a suitable learning method (DeVries et al. 1975). TGT allows students to study in heterogeneous groups sorted by gender and learning achievement (Tarim \& Akdeniz, 2008). The central concepts of this model are teamwork, individual accountability, social skills, faceto-face interaction, group processing, and every student has an equal opportunity (Johnson \& Johnson, 1994); (Wyk, 2011). It means that each individual in the group must contribute and strive to succeed. Cooperative learning emphasizes forming small groups of students with different abilities and backgrounds who pursue individual and group performance through communication, teamwork, and maintaining trust (Dyson, 2002). Several previous results recommend that cooperative learning is effective in improving various learning skills (Casey \& Quennerstedt, 2020), motor skills (Bores-García et al., 2021), learning outcomes (Mentz \& Zyl, 2018), emotional intelligence (Wattanawongwan et al., 2021), critical thinking skills (Matchett, 2009), social skills (Tran, 2014), creativity (Gossett \& Fischer, 2005; Segundo Marcos et al., 2020), problem-solving skills (Alpaslan, 2016), and motivation (Artha et al., 2020).

Regular exercise is essential for a healthy life and affects mental and physical development (Hills et al., 2007). However, many people face barriers to exercising regularly due to high work activity (Visier-Alfonso et al., 2021). In adolescence, a decrease in physical activity has become noticeable. For example, $12 \%$ of girls and $19.1 \%$ of boys aged 11 to 15 in Germany achieve a level of physical activity of 60 minutes per day (Engels \& Freund, 2020). Exercise during childhood has many benefits on physical and mental health and motor and cognitive development (Timmons et al., 2012; WHO, 2016). It prevents overweight and obesity during childhood and adolescence (Bisson et al., 2019). In this activity, $91 \%$ of children 2-17 years, $99 \%$ of boys, and $94 \%$ of girls in America prefer to play online games. This potential is hazardous associated with aggression, addiction, and depression (Ferguson \& Olson, 2013). Under these circumstances, teachers must design gameoriented learning tools, one of which is TGT type cooperative learning for students. It can be seen that in recent years the interest in game-based learning for students has increased (Vlachopoulos \& Makri, 2017). Physical education learning makes more use of various physical activities to produce holistic changes in the form of improving the physical quality of individuals and mentally and emotionally (Knaeps et al., 2017).

Physical, cognitive, social, and affective learning is positioned as a legitimate learning outcome from physical education. It has been argued that these four learning outcomes aim to facilitate 
student engagement with physically active lives (Bailey et al., 2009; Kirk, 2013). Cooperative Learning is a pedagogical model that can support these four learning outcomes (Kristiansen et al., 2019). The results of previous studies explain that TGT can improve students' cognitive learning outcomes (Ke, 2008). This is because TGT offers students' physical education learning outcomes in a better direction when compared to traditional learning models (Morgan, 2019). Slavin (2015) described that the cooperative learning model affects learning, which is shown in Figure 1.

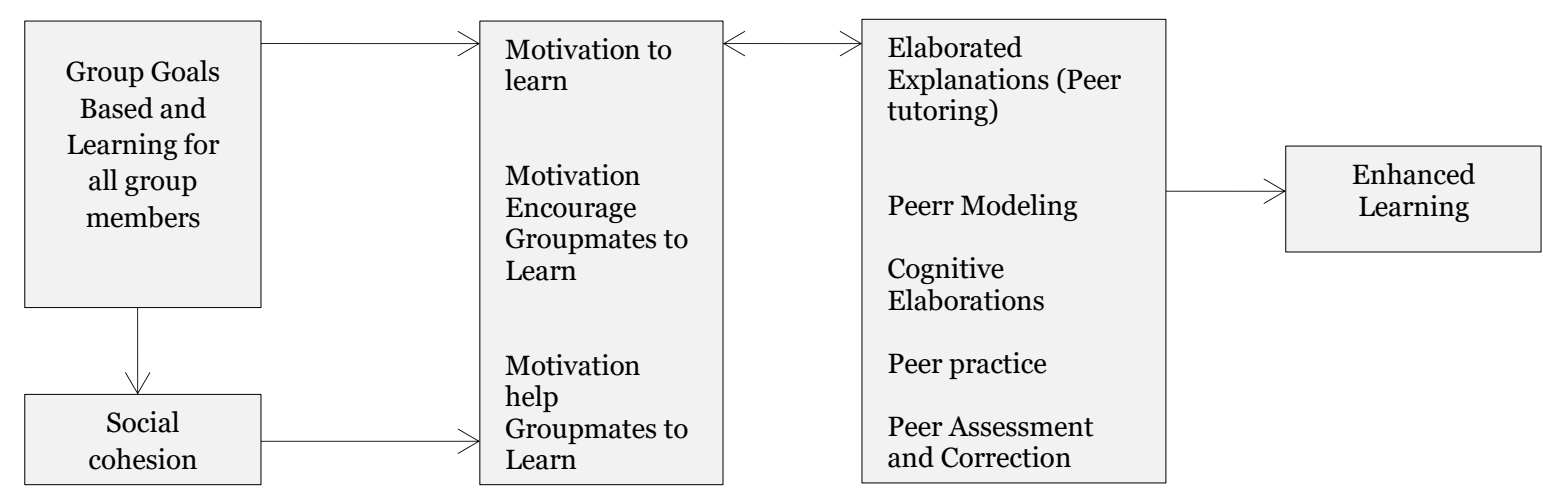

Figure 1. Cooperative Learning Model Has An Effect On Learning

Within the framework of physical education in Indonesia, cognitive learning outcomes are still the focus of attention for teachers and the main target of students (Andriyani et al., 2021). Cognitive learning outcomes represent students' intellectual intelligence (Holmlund \& Silva, 2014). Several government policies are carried out from time to time to improve student learning in order to get the expected results (Lewis \& Nguyen, 2020). Therefore, the learning, practice, and evaluation scheme must involve the cognitive aspects on an ongoing basis (Brewis, 2019). Learning patterns in AmbonIndonesia, especially physical education subjects, tend to focus on low cognitive (Fenanlampir \& Mutohir, 2021). That is because many teachers think that students have not been able to think at a higher level (Leasa, Fenanlampir, et al., 2021).

The classroom is an academic space with intellectual diversity (Kuiken \& Vedder, 2021). One of the things that cannot be avoided is the difference in students' academic abilities (Albus et al., 2021). In a cooperative classroom atmosphere, heterogeneity is one of the main concerns of teachers (Hunter et al., 2016; Leasa et al., 2019). In addition to promoting students to think and practice knowledge, heterogeneity also equips students to build good social relations or competition between students (Peña-Ayala, 2021). Different students' academic abilities can be facilitated in TGT learning (Slavin, 1980; Salam et al., 2015). Students with low learning outcomes and high cognitive learning outcomes tend to have many differences (Leasa, Batlolona, et al., 2021). In the classroom, students are faced with more challenging situations, have different self-motivation, and are more idealistic to be the best (Chan, 2020). The TGT cooperative type learning model allows students with high and low cognitive abilities to help and motivate each other to improve students' cognitive learning outcomes (Tarhan \& Acar Sesen, 2012). There are many different forms of cooperative learning, such as Teams-Games-Tournament (TGT), Jigsaw, Cooperative Integrated Reading and Composition (CIRC), Learning Together (LT), Student Teams-Achievement Divisions (STAD), Team Assisted Individualization (TAI), Academic Controversy (AC), Group Investigation (GI), etc. (Kagan, 1992). The idea underlying all cooperative learning methods is that students work together to learn and are responsible for their group and their learning (Slavin, 2008; Slavin, 2014).

One of the topics recommended in this study is relay running. Students must play together in groups and try to win the game in this game. This game is played in teams. Each student must be responsible for doing his part (Saavedra et al., 2014). Therefore, every student must have a good strategy and technique in speed in the running. Students must be alert to the instructions for the 
start of the game and the movements of their friends. Relay is a game where equal teams compete to achieve a task. Relay running provides an excellent opportunity for teams to compete against each other. Relay running combines individual and teamwork-based tasks (Darby et al., 2020). In this way, students can work together and help each other, but still allow individuals to practice their skills and what they have learned without always depending on the help of others (Hüffmeier et al., 2017). Relay running is one of the numbers in athletics. Relay running is a team run, where runners take turns taking turns carrying the baton from the start line to the finish line. Relay running is one of the events competed in the 4x100 $\mathrm{m}$ and 4x400 men and women (Wu et al., 2021). One of the greatest athletes in athletic history is Usain Bolt, winner of eight golds in Olympic history and world records in the $100 \mathrm{~m}$ and $4 \times 400 \mathrm{~m}$ (Čoh et al., 2018). It is a description of relay running, so we explored how to relay running for students with TGT improves cognitive learning outcomes through this research. Physical education learning in elementary schools with the concept of relay running with the TGT type of cooperative learning model is rarely studied. TGT is measured and researched in specific fields of science, for example, in economics learning (Wyk, 2012), Health (Wodarski et al., 2004), and accounting education (Tanner \& Lindquist, 1998). Therefore, through this research, it is explored deeper. The purpose of this study was to determine the effect of the TGT cooperative type learning model on students' cognitive learning outcomes on the topic of relay running.

\section{METHOD}

This study used a quantitative approach. This experimental method with a quasi-experimental research design used a nonequivalent control group design. This design was carried out to investigate the effect of the TGT cooperative type on students' cognitive learning outcomes, according to Table

1.

Table 1. Research Design of Nonequivalent Control Group Design

\begin{tabular}{cccc}
\hline Group & PretesT & Treatment & Posttest \\
\hline Experiment & $\mathrm{Y}_{1}$ & $\mathrm{X}_{1}$ & $\mathrm{Y}_{2}$ \\
Control & $\mathrm{Y}_{3}$ & $\mathrm{X}_{2}$ & $\mathrm{Y}_{4}$ \\
\hline
\end{tabular}

\section{Where,}

$\left(\mathrm{X}_{1}\right)$ : The group that was treated using the TGT cooperative type model

$\left(\mathrm{X}_{2}\right)$ : Groups with the method used in school

$\left(\mathrm{Y}_{1}\right)$ : Measurement of the initial ability of the experimental group

$\left(\mathrm{Y}_{2}\right)$ : Measurement of the final ability of the experimental group

$\left(\mathrm{Y}_{3}\right)$ : Measurement of the initial ability of the control group

$\left(\mathrm{Y}_{4}\right)$ : Measurement of the final ability of the control group

The population in this study were all fifth-grade students in an elementary school in Langgur, Southeast Maluku. The sample in this study amounted to 70 students consisting of an experimental group of 35 students and 35 students as a control group. The experimental class consisted of 20 male students and 15 female students. The control class consisted of 26 male students and 9 female students. The average fifth grader is 10-11 years old. The sampling technique was done by random sampling technique. The schools referred to in this study were included in the medium-level category. The research instrument used was pretest and posttest, which were used to determine students' cognitive learning outcomes. The pretest was carried out in the class before being given treatment, and the posttest was carried out after treatment. The test instrument consisted of 10 description questions that are feasible because they have reached valid and reliable indicators (0.797). Before this question was given to the experimental class, 3 physical education experts validated it. They were 2 experts from Pattimura University and 1 expert from elementary school teachers who had a master's degree background. The purpose of taking experts from teachers was to provide input related to the material and test questions according to the needs of elementary school students. The data obtained were then analyzed based on data analysis techniques, including descriptive analysis, assumption or prerequisite tests, and hypothesis testing. After being tested for normality and homogeneity, the average difference was made for the achievement of the two classes. 
The analysis used was the analysis of the ANCOVA test with a significant level of 0.05 on the SPSS 23 software.

\section{FINDINGS AND DISCUSSION}

Cognitive learning outcomes with TGT in the experimental and control classes in the form of pretest and posttest as many as 10 questions can be seen in Figure 2.

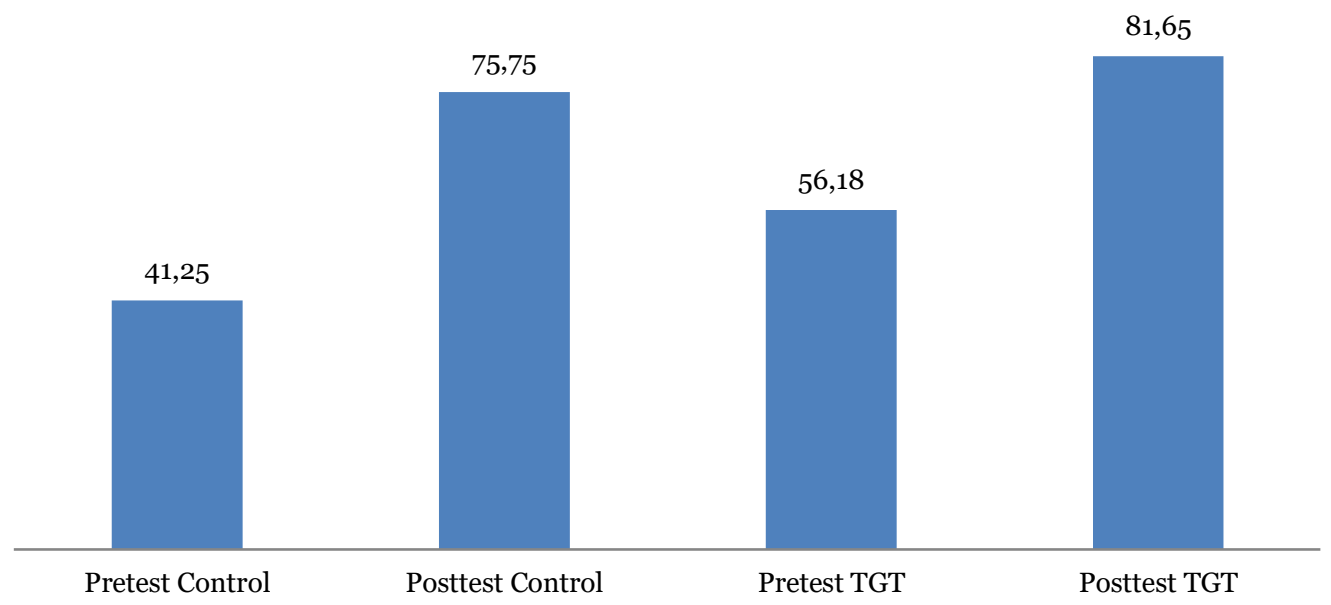

\section{Figure 2. The Results of The Pretest and Posttest In The Experimental and Control Classes}

Graph 2 shows that the TGT post-test score is superior to the control class. Thus, TGT effectively improves students' cognitive learning outcomes on the topic of relay running. The analysis prerequisite test (normality and homogeneity tests) showed that the two classes were normally distributed and had homogeneous variance. Then hypothesis testing was carried out using the ANCOVA test, which aimed to see the effect of the TGT model on the. Students' cognitive learning results. The results of the ANCOVA test of students' cognitive learning outcomes in the TGT model treatment are shown in Table 2.

Table 2. ANCOVA Test on the Effect of the TGT Model on Cognitive Learning Outcomes

\begin{tabular}{lrrrrr}
\hline \multicolumn{1}{c}{ Source } & $\begin{array}{c}\text { Type III Sum of } \\
\text { Squares }\end{array}$ & df & Mean Square & \multicolumn{1}{c}{ F } & \multicolumn{1}{c}{ Sig. } \\
\hline Corrected Model & $4824.222^{\mathrm{a}}$ & 3 & 1608.074 & 329.861 & .000 \\
Intercept & 212213.778 & 1 & 212213.778 & $4.353 \mathrm{E} 4$ & .000 \\
Model & 658.778 & 1 & 658.778 & 135.134 & .000 \\
Tes Awal & 4096.000 & 1 & 4096.000 & 840.205 & .000 \\
Model Pembelajaran & 69.444 & 1 & 69.444 & 14.245 & .001 \\
Error & 156.000 & 32 & 4.875 & & \\
Total & 217194.000 & 36 & & & \\
Corrected Total & 4980.222 & 35 & & & \\
\hline
\end{tabular}

These results measure the value of sig $=0.001$, which is smaller than sig $=0.05$. It means that the learning model affects science learning outcomes. In the learning model, it can be seen that Fcount 14,245 with a significance of 0.001 far below the value of sig <0.05, then Ho is rejected while $\mathrm{Ha}$ is accepted. It can be concluded that there is a difference in learning outcomes between those who follow the learning using the TGT model and the conventional model. 
The TGT class is superior to the control class. It is because the cooperative-based TGT model emphasizes togetherness or cooperation learning. A unique teaching system like this can allow students to collaborate and share knowledge to complete assignments given by the teacher. Through groups, students will act as learning resources to gather information and help each other achieve success (Sugiharto, 2020). Group cooperation shows that the group's success is determined by learning together in groups. Therefore, in one group, students will be positively responsible. In addition, each group member has individual responsibilities and the opportunity to contribute to the group's success in the relay running. The following Figure 3 shows some of the relay running techniques.

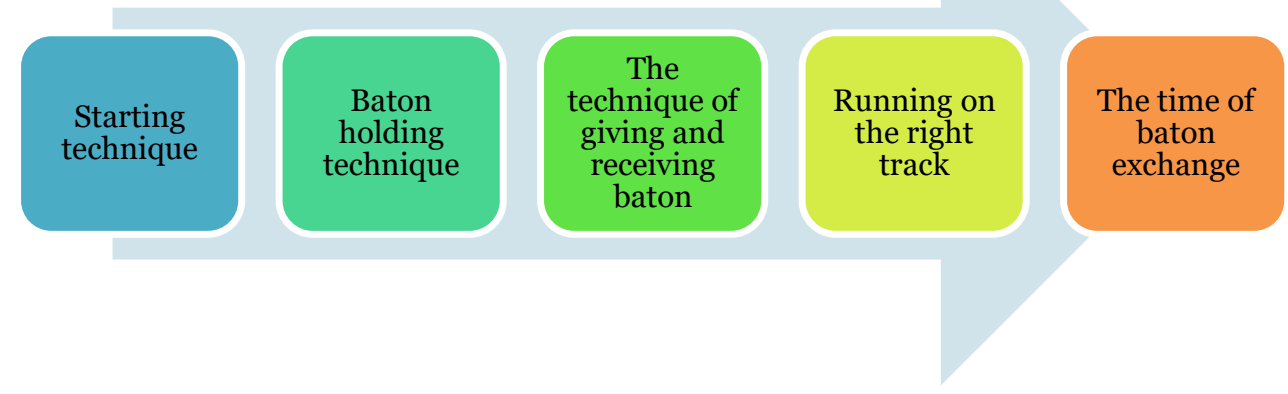

\section{Figure 3. Some Relay Running Techniques}

Physical education educates students in an assignment and plans to learn activities that will result in students becoming more skilled and understanding the history, traditions, and nuances of the sport and becoming willing participants in sports culture. Sports learning is a learning model that connects the sports taught in physical education to the broader sports culture. Sports learning places students in small teams and takes them through a range of skill practices and developmentally appropriate play with authentic competition (Dyson, 2004). With TGT, cooperative type learning, as a mode of learning, provides opportunities for students to develop skills well. Everyone usually has essential skills to manage to produce the expected goals adequately. In the TGT class, students interact in groups and work with others. This phenomenon is expected by the world today. The findings based on existing data indicate that the learning outcomes of students with TGT are higher (81.65) when compared to conventional learning (75.75). It follows the findings of Wyk (2011), which also explains that the TGT academic achievement score is higher when compared to the control class. It signals that the TGT group is more skilled in academic achievement when compared to traditional classes.

Cooperative emphasizes collaboration, problem-solving, conflict resolution, and working together, which are essential life skills and group students in heterogeneous or homogeneous classes. Groupings can be categorized based on gender, age, interests, and intelligence. (Wyman \& Watson, 2020). Besides that, it also has different ethnicities and different cultures (Erbil \& Kocabaş, 2018). This form offers opportunities for interactive engagement, appears to encourage student participation, stimulates critical thinking, and requires peer interaction (Tlhoaele et al., 2014). Students in Australia, Singapore, and Malaysia work in culturally similar peer groups where group members agree rather than challenge their way of thinking (Hennebry \& Fordyce, 2018). Over the past 20 years, more and more research on the theory and practice of cooperative learning has been linked to physical education in improving students' academics (Goodyear et al., 2014). Regarding the physical domain, cooperative learning has been associated with improved motor skills, sport technique, and game performance, leading to increased levels of physical activity (Casey, 2014). Relay running is one of the materials favored by elementary school children, which trains fitness, 
strength, builds strategy, reasoning, and intellectual intelligence. It also develops other pedagogical elements to foster empathy, caring, mutual respect, support, encouragement, or teamwork. Values related to this pedagogical model encourage good social relations among students (Fernandez-Rio et al., 2017).

Cooperative learning can promote deep learning by encouraging interaction and diversity of perspectives among students. Thus, compared to traditional, competitive, and individualistic approaches, cooperative learning has significantly positively impacted student achievement and learning perceptions that lead to improvements in students' academic and moral cognition (Arena \& Davis, 2021). Scientists agree on the five elements developed by Johnson \& Johnson (1994), as shown in Figure 4.

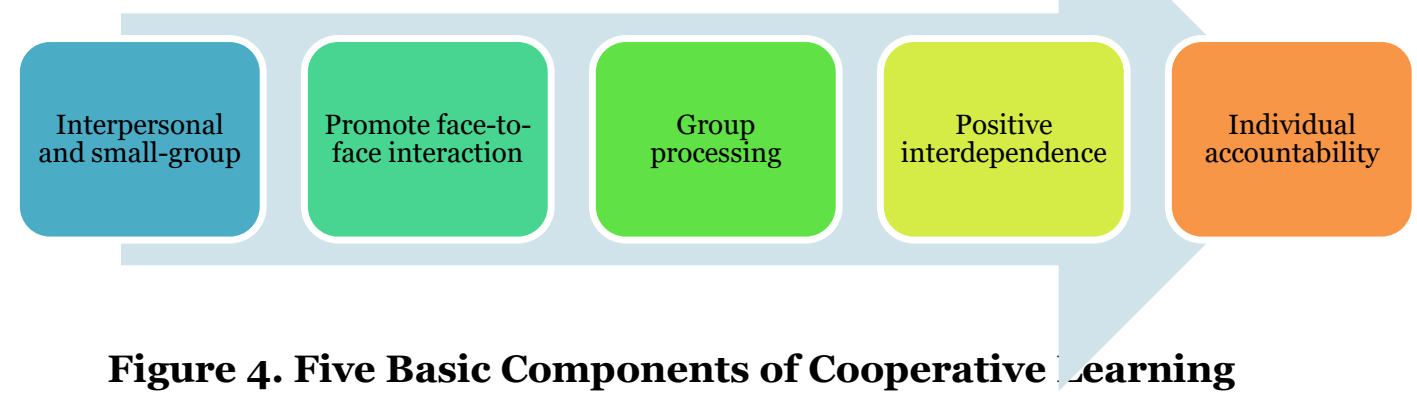

Teachers need to apply learner-centred methods and strategies. The cooperative method serves as an alternative way of teaching to promote speaking and social interaction among students (Ning, 2011). Cooperative learning is a pedagogical activity that allows positive social interaction and respects diversity, individual needs, and student learning patterns. Students work together in mixed ability playgroups to maximize their learning to achieve a common goal. With cooperative learning, students can act as speakers in learning through dialogue to express opinions, points of view, offer hypotheses and provide input into assignments given by the teacher. In cooperative learning, students develop positive attitudes towards tasks and interpersonal relationships. They tend to improve communication skills and implicit interactions in structured work. This goal can increase motivation in children with low academics, promote analytical skills, and develop other skills related to reasoning and conceptualization.

\section{CONCLUSION}

Based on the findings, it can be concluded that the TGT cooperative type learning model affects students' cognitive learning outcomes on the concept of relay running. This is because TGT is a cooperative model that can stimulate students to be enthusiastic in playing and learning. The golden age of elementary school children is playing and learning. Students feel happy and excited when their talents and interests are facilitated in learning that must be in class all the time. Thus, the TGT cooperative model can be recommended in increasing students' cognitive learning outcomes on the concept of relay running. The suggestions are, 1) It is expected that physical education teachers can carry out TGT activities for other materials or topics in the field of sports, 2) For schools and local and central governments to be able to facilitate teachers and students in the form of good fields or teaching aids that can support and create young seeds of the nation's golden generation to support sports achievements both student and general scale in the future, 3) further research is expected to research on improving middle and high school for other topics in physical education with the TGT model in improving learning outcomes students, critical, problem-solving, creativity and innovation of student thinking. 


\section{REFERENCE}

Albus, P., Vogt, A., \& Seufert, T. (2021). Signaling in virtual reality influences learning outcome and $\begin{array}{llll}\text { cognitive load. Computers and Education, } 166, & 104154 .\end{array}$ https://doi.org/10.1016/j.compedu.2021.104154

Alpaslan, G. (2016). The investigation of the effects of physical education lessons planned in accordance with cooperative learning approach on secondary school students problem solving skills. Educational Research and Reviews, 11(10), 998-1007. https://doi.org/10.5897/err2016.2756

André, A., Deneuve, P., \& Louvet, B. (2011). Cooperative learning in physical education and acceptance of students with learning disabilities. Journal of Applied Sport Psychology, 23(4), 474-485. https://doi.org/10.1080/10413200.2011.580826

Andriyani, F. D., Biddle, S. J. H., \& De Cocker, K. (2021). Adolescents' physical activity and sedentary behaviour in Indonesia during the COVID-19 pandemic: a qualitative study of mothers' perspectives. BMC Public Health, 21(1), 1-14. https://doi.org/10.1186/s12889-021-11931-1

Arena, S. L., \& Davis, J. L. (2021). The concept-specific effects of cooperative learning in an introductory engineering mechanics dynamics course. Innovations in Education and Teaching International, 58(4), 387-397. https://doi.org/10.1080/14703297.2020.1777886

Artha, A. A., Syam T, A. R., \& Priambodo, A. (2020). The application of teams games tournament (TGT) and teaching game for understanding (TGfU) learning models on learning motivation and volley ball passing skills. Budapest International Research and Critics in Linguistics and Education (BirLE) Journal, 3(1), 46-53. https://doi.org/10.33258/birle.v3i1.751

Bailey, R., Armour, K., Kirk, D., Jess, M., Pickup, I., \& Sandford, R. (2009). The educational benefits claimed for physical education and school sport: An academic review. Research Papers in Education, 24(1), 1-27. https://doi.org/10.1080/02671520701809817

Bisson, M., Tremblay, F., Pronovost, E., Julien, A. S., \& Marc, I. (2019). Accelerometry to measure physical activity in toddlers: Determination of wear time requirements for a reliable estimate of physical activity. Journal of Sports Sciences, 37(3), 298-305. https://doi.org/10.1080/02640414.2018.1499391

Bjørke, L., \& Mordal Moen, K. (2020). Cooperative learning in physical education: a study of students' learning journey over 24 lessons. Physical Education and Sport Pedagogy, 25(6), 600-612. https://doi.org/10.1080/17408989.2020.1761955

Bores-García, D., Hortigüela-Alcalá, D., Fernandez-Rio, F. J., González-Calvo, G., \& Barba-Martín, R. (2021). Research on cooperative learning in physical education: systematic review of the last five years. Research Quarterly for Exercise and Sport, 92(1), 146-155. https://doi.org/10.1080/02701367.2020.1719276

Brewis, E. (2019). Fair access to higher education and discourses of development: a policy analysis from Indonesia. Compare, 49(3), 453-470. https://doi.org/10.1080/03057925.2018.1425132

Casey, A. (2014). Models-based practice: Great white hope or white elephant? Physical Education and Sport Pedagogy, 19(1), 18-34. https://doi.org/10.1080/17408989.2012.726977

Casey, A., \& Fernandez-Rio, J. (2019). Cooperative learning and the affective domain. Journal of Physical Education, Recreation and Dance, 90(3), 12-17. https://doi.org/10.1080/07303084.2019.1559671

Casey, A., \& Quennerstedt, M. (2020). Cooperative learning in physical education encountering Dewey's educational theory. European Physical Education Review, 26(4), 1023-1037. https://doi.org/10.1177/1356336X20904075

Chan, M. (2020). A multilevel SEM study of classroom talk on cooperative learning and academic achievement: Does cooperative scaffolding matter? International Journal of Educational Research, 101(March), 101564. https://doi.org/10.1016/j.ijer.2020.101564

Čoh, M., Hébert-Losier, K., Štuhec, S., Babić, V., \& Supej, M. (2018). Kinematics of Usain Bolt’s maximal sprint velocity. Kinesiology, $5 O(2), 172-180$. https://doi.org/10.26582/K.50.2.10

Darby, W., Bergeron, P., Brown, N., DeFoor, M., \& Jones, B. (2020). Escape room relay race: "Go for the gold" in formative assessment. Journal of Nursing Education, 59(11), 646-650. https://doi.org/10.3928/01484834-20201020-09

DeVries D L, Mescon IT, Shackman SL 1975. TeamsGames- Tournament in the Elementary Classroom: A Replication (Tech. Rep. No. 190). Baltimore: Johns Hopkins University, Center for Social Organization of Schools. 
Dyson, B. (2002). The implementation of cooperative learning in an elementary physical education program. Journal of Teaching in Physical Education, 22(1), 69-85. https://doi.org/10.1123/jtpe.22.1.69

Dyson, B., Griffin, L. L., \& Hastie, P. (2004). Sport education, tactical games, and cooperative learning: theoretical and pedagogical considerations. Quest, 56(2), 226240. https://doi.org/10.1080/00336297.2004.1049182

Engels, E. S., \& Freund, P. A. (2020). Effects of cooperative games on enjoyment in physical education-How to increase positive experiences in students? PLOS ONE, 15(12 December), 114. https://doi.org/10.1371/journal.pone.0243608

Erbil, D. G., \& Kocabaş, A. (2018). Cooperative Learning as a Democratic Learning Method. Journal of Research in Childhood Education, 32(1), 81-93. https://doi.org/10.1080/02568543.2017.1385548

Fenanlampir, A., \& Mutohir, T. C. (2021). Emotional intelligence and learning outcomes: Study in physical education. Journal Sport Area, 6(3), 304-314. https://doi.org/10.25299/sportarea.2021.vol6(3).6836

Ferguson, C. J., \& Olson, C. K. (2013). Friends, fun, frustration and fantasy: Child motivations for video game play. Motivation and Emotion, 37(1), 154-164. https://doi.org/10.1007/s11031012-9284-7

Fernandez-Rio, J., Sanz, N., Fernandez-Cando, J., \& Santos, L. (2017). Impact of a sustained Cooperative Learning intervention on student motivation. Physical Education and Sport Pedagogy, 22(1), 89-105. https://doi.org/10.1080/17408989.2015.1123238

Goodyear, V. A., Casey, A., \& Kirk, D. (2014). Hiding behind the camera: Social learning within the Cooperative Learning Model to engage girls in physical education. Sport, Education and Society, 19(6), 712-734. https://doi.org/10.1080/13573322.2012.707124

Gossett, M., \& Fischer, O. (2005). Bringing together critical thinking and cooperative learning between two schools. Strategies, 19(2), 27-30. https://doi.org/10.1080/08924562.2005.10591181

Groffik, D., Mitáš, J., Jakubec, L., Svozil, Z., \& Frömel, K. (2020). Adolescents' physical activity in education systems varying in the number of weekly physical education lessons. Research Quarterly for Exercise and Sport, 91(4), 551-561. https://doi.org/10.1080/02701367.2019.1688754

He, J., Barrera-Pedemonte, F., \& Buchholz, J. (2019). Cross-cultural comparability of noncognitive constructs in TIMSS and PISA. Assessment in Education: Principles, Policy and Practice, 26(4), 369-385. https://doi.org/10.1080/0969594X.2018.1469467

Healy, M., Doran, J., \& McCutcheon, M. (2018). Cooperative learning outcomes from cumulative experiences of group work: differences in student perceptions. Accounting Education, 27(3), 286-308. https://doi.org/10.1080/09639284.2018.1476893

Hennebry, M. L., \& Fordyce, K. (2018). Cooperative learning on an international masters. Higher Education Research and Development, 37(2), 270-284. https://doi.org/10.1080/07294360.2017.1359150

Hills, A. P., King, N. A., \& Armstrong, T. P. (2007). Contribution of physical activity and sendentary bahaviours to the growth and development of children and adolescents. Sports Medicine, 37(6), 533-545. https://link.springer.com/article/10.2165/00007256-200737060-00006

Holmlund, H., \& Silva, O. (2014). Targeting noncognitive skills to improve cognitive outcomes: evidence from a remedial education intervention. Journal of Human Capital, 8(2), 126-160. https://doi.org/10.1086/676460

Hüffmeier, J., Filusch, M., Hertel, G., Mojzisch, A., \& Krumm, S. (2017). On the boundary conditions of effort losses and effort gains in action teams. Journal of Applied Psychology, 102(12), 16731685. https://doi.org/10.1037/aplooo0245

Hunter, W. C., Dieker, L. A., \& Whitney, T. (2016). Consultants and coteachers affecting student outcomes with numbered heads together: keeping all engaged. Journal of Educational and Psychological Consultation, 26(2), 186-199. https://doi.org/10.1080/10474412.2015.1108200

Johnson, D., \& Johnson, R. (1994). Learning Together and Alone: Cooperative, Competitive, and Individualistic Learning, 4th ed.; Allyn \& Bacon: Boston, MA, USA.

Kagan, S. (1992). Cooperative learning. Paseo Espada: Resources for Teachers, Inc.

Ke, F. (2008). Computer games application within alternative classroom goal structures: Cognitive, metacognitive, and affective evaluation. Educational Technology Research and Development, 


$$
\text { 56(5-6), 539-556. https://doi.org/10.1007/s11423-0o8-9086-5 }
$$

Kirk, D. (2013). Educational Value and Models-based practice in physical education. Educational Philosophy and Theory, 45(9), 973-986. https://doi.org/10.1080/00131857.2013.785352

Knaeps, S., Bourgois, J. G., Charlier, R., Mertens, E., \& Lefevre, J. (2017). Associations between physical activity and health-related fitness-volume versus pattern. Journal of Sports Sciences, 35(6), 539-546. https://doi.org/10.1080/02640414.2016.1178393

Kristiansen, S. D., Burner, T., Johnsen, B. H., Dzemidzic, S., Burner, T., Johnsen, B. H., Kristiansen, S. D., Burner, T., \& Johnsen, B. H. (2019). Face-to-face promotive interaction leading to successful cooperative learning : A review study Face-to-face promotive interaction leading to successful cooperative learning: A review study. Cogent Education, 6(01). https://doi.org/10.1080/2331186X.2019.1674067

Kuiken, F., \& Vedder, I. (2021). The interplay between academic writing abilities of Dutch undergraduate students, a remedial writing programme, and academic achievement. International Journal of Bilingual Education and Bilingualism, 24(10), 1474-1485. https://doi.org/10.1080/13670050.2020.1726280

Leasa, M., Batlolona, J. R., \& Talakua, M. (2021). Elementary students ' creative thinking skills in science in the Maluku Islands , Indonesia. Creativity Studies, 14(1), 74-89.

Leasa, M., Fenanlampir, A., Batlolona, J. R., \& Saimima, A. S. (2021). Problem-solving and creative thinking skills with the PBL model: The concept of the human circulatory system. Biosfer: Jurnal Pendididakan Biologi, 14(2), 154-166.

Leasa, M., Sanabuky, Y. L., Batlolona, J. R., \& Enriquez, J. J. (2019). Jigsaw in teaching circulatory system: a learning activity on elementary science classroom. Biosfer: Jurnal Pendidikan Biologi, 12(2), 122-134. https://doi.org/10.21009/biosferjpb.v12n2.122-134

Leasa, M., Talakua, M., \& Batlolona, J. R. (2016). The development of a thematic module based on Numbered Heads Together (NHT) cooperative learning model for elementary students in Ambon, Moluccas-Indonesia. New Educational Review, 46(4), 174-185. https://doi.org/10.15804/tner.2016.46.4.15

Lenhart, A., Kahne, J., Middaugh, E., Macgill, A. R., Evans, C., \& Vitak, J. (2008). Teens, video games, and civics: Teens' gaming experiences are diverse and include significant social interaction and civic engagement. Pew Internet \& American Life Project. Retrieved from the Pew Internet \& American Life Project website: http://www.pewinternet.org/ Reports/2008/Teens-Video-Games-and-Civics.aspx

Lewis, B. D., \& Nguyen, H. T. M. (2020). Assessing the causal impact of compulsory schooling policy in Indonesia. International Journal of Educational Research, 104(October), 101693. https://doi.org/10.1016/j.ijer.2020.101693

Liebech-Lien, B. (2021). Teacher teams - A support or a barrier to practising cooperative learning? Teaching and Teacher Education, 106, 103453. https://doi.org/10.1016/j.tate.2021.103453

Luo, Y. J., Lin, M. L., Hsu, C. H., Liao, C. C., \& Kao, C. C. (2020). The effects of team-gametournaments application towards learning motivation and motor skills in college physical education. Sustainability, 12(15), 1-12. https://doi.org/10.3390/su12156147

Matchett, N. J. (2009). Cooperative Learning, critical thinking, and character: techniques to cultivate ethical deliberation. Public Integrity, 12(1), 25-38. https://doi.org/10.2753/PIN1099-9922120102

Mentz, E., \& Zyl, S. Van. (2018). The impact of cooperative learning on self- directed learning abilities in the computer applications technology class. International Journal of Lifelong Education, oo(oo), 1-13. https://doi.org/10.1080/02601370.2018.1513426

Morgan, K. (2019). Applying Mastery TARGET structures to cooperative learning in physical education. Journal of Physical Education, Recreation and Dance, 90(3), 27-32. https://doi.org/10.1080/07303084.2019.1559677

Peña-Ayala, A. (2021). A learning design cooperative framework to instill 21st century education. Telematics and Informatics, 62(May), 1-16. https://doi.org/10.1016/j.tele.2021.101632

Rivera-Pérez, S., León-Del-barco, B., Fernandez-Rio, J., González-Bernal, J. J., \& Gallego, D. I. (2020). Linking cooperative learning and emotional intelligence in physical education: Transition across school stages. International Journal of Environmental Research and Public Health, 17(14), 1-11. https://doi.org/10.3390/ijerph17145090

Saavedra, J. M., García-Hermoso, A., Escalante, Y., Dominguez, A. M., Arellano, R., \& Navarro, F. (2014). Relationship between exchange block time in swim starts and final performance in relay 
races in international championships. Journal of Sports Sciences, 32(19), 1783-1789. https://doi.org/10.1080/02640414.2014.920099

Salam, A., Hossain, A., \& Rahman, S. (2015). Teams games tournaments ( TGT ). cooperative technique for learning mathematics in secondary schools in Bangladesh. Malaysian Online $\begin{array}{llll}\text { Journal of } & \text { Educational 271-287. }\end{array}$ https://doi.org/10.4471/redimat.2015.1519

Segundo Marcos, R. I., López Ferández, V., Daza González, M. T., \& Phillips-Silver, J. (2020). Promoting children's creative thinking through reading and writing in a cooperative learning classroom. Thinking Skills and Creativity, 36, 100663. https://doi.org/10.1016/j.tsc.2020.100663

Slavin, R. E. (1980). Cooperative Learning. Review of Educational Research, 5o(2), 315-342. https://doi.org/10.3102/00346543050002315

Slavin, R. E. (2008). Cooperative Learning, Success for All, and Evidence-based Reform in $\begin{array}{lllll}\text { education. É Elucation } & \text { Et } & \text { Didactique, } & 2-2, & 149-157 .\end{array}$ https://doi.org/10.4000/educationdidactique.334

Slavin, R. E. (2014). Cooperative learning and academic achievement: Why does groupwork work? Cooperative Learning and Academic Achievement: Why Does Groupwork Work?, 30(3), 785791. https://doi.org/10.6018/analesps.30.3.201201

Slavin, R. E. (2015). Cooperative learning in elementary schools. Education 3-13, 43(1), 514. https://doi.org/10.1080/03004279.2015.963370

Sugiharto. (2020). Geographical students' learning outcomes on basic political science by using cooperative learning model with Group Investigation (GI) type in State University of Medan, Indonesia. Journal of Human Behavior in the Social Environment, 30(4), 447456. http://doi.org/10.1080/10911359.2019.1696261

Tanner, M. M., \& Lindquist, T. M. (1998). Teaching resource using monopoly TM and TeamsGamesTournaments in accounting education: a cooperative learning teaching resource. Accounting Education, 7(2), 139-162. doi:10.1080/096392898331225

Tarhan, L., \& Acar Sesen, B. (2012). Jigsaw cooperative learning: Acid-base theories. Chemistry Education Research and Practice, 13(3), 307-313. https://doi.org/10.1039/c2rp90004a

Tarim, K., \& Akdeniz, F. (2008). The effects of cooperative learning on Turkish elementary students' mathematics achievement and attitude towards mathematics using TAI and STAD methods. Educational Studies in Mathematics, 67(1), 77-91. https://doi.org/10.1007/s10649-0079088-y

Timmons, B. W., Leblanc, A. G., Carson, V., Gorber, S. C., Dillman, C., Janssen, I., Kho, M. E., Spence, J. C., Stearns, J. A., \& Tremblay, M. S. (2012). Systematic review of physical activity and health in the early years (aged o-4 years). Applied Physiology, Nutrition and Metabolism, 37(4), 773-792. https://doi.org/10.1139/H2012-070

Thoaele, M., Hofman, A., Winnips, K., \& Beetsma, Y. (2014). The impact of interactive engagement methods on students' academic achievement. Higher Education Research and Development, 33(5), 1020-1034. https://doi.org/10.1080/07294360.2014.890571

Tran, V. D. (2014). The effects of cooperative learning on the academic achievement and knowledge retention. International Journal of Higher Education, 3(2), 131-140. https://doi.org/10.5430/ijhe.v3n2p131

Visier-Alfonso, M. E., Álvarez-Bueno, C., Sánchez-López, M., Cavero-Redondo, I., MartínezHortelano, J. A., Nieto-López, M., \& Martínez-Vizcaíno, V. (2021). Fitness and executive function as mediators between physical activity and academic achievement: Mediators between physical activity and academic achievement. Journal of Sports Sciences, 39(14), 1576-1584. https://doi.org/10.1080/02640414.2021.1886665

Vlachopoulos, D., \& Makri, A. (2017). The effect of games and simulations on higher education: a systematic literature review. In International Journal of Educational Technology in Higher Education (Vol. 14, Issue 1). https://doi.org/10.1186/s41239-017-0062-1

Wattanawongwan, S., Smith, S. D., \& Vannest, K. J. (2021). Cooperative learning strategies for building relationship skills in students with emotional and behavioral disorders. Beyond Behavior, 30(1), 32-40. https://doi.org/10.1177/1074295621997599

WHO. (2016). Report of the commission on ending childhood obesity. Retrieved from http://apps.who.int/iris/bitstream/10665/204176/1/9789241510066_eng.pdf?ua=1

Wodarski, J. S., Wodarski, L. A., \& Parris, H. N. (2004). Adolescent Preventive Health and Teams- 
Games-Tournaments. Journal of Evidence-Based Social Work, 1(1), 101124. doi:10.1300/j394vo1no1_06

Wu, P. P. Y., Babaei, T., O’Shea, M., Mengersen, K., Drovandi, C., McGibbon, K. E., Pyne, D. B., Mitchell, L. J. G., \& Osborne, M. A. (2021). Predicting performance in 4 x 200-m freestyle swimming relay events. PLOS ONE, 16, 1-13. https://doi.org/10.1371/journal.pone.0254538

Wyk, M. M. van. (2011). The effects of teams-games-tournaments on achievement, retention, and attitudes of economics education students. Journal of Social Sciences, 26(3), 183-193. https://doi.org/10.1080/09718923.2011.11892895

Wyman, P. J., \& Watson, S. B. (2020). Academic achievement with cooperative learning using homogeneous and heterogeneous groups. School Science and Mathematics, 120(6), 356-363. https://doi.org/10.1111/ssm.12427 